\title{
Prefrontal Cortex Stimulation Induces 2-Arachidonoyl- Glycerol-Mediated Suppression of Excitation in Dopamine Neurons
}

\author{
Miriam Melis, ${ }^{1,2 *}$ Simona Perra, ${ }^{1,2 *}$ Anna Lisa Muntoni, ${ }^{1,3}$ Giuliano Pillolla, ${ }^{1,2}$ Beat Lutz, ${ }^{4}$ Giovanni Marsicano, ${ }^{4}$ \\ Vincenzo Di Marzo, ${ }^{5}$ Gian Luigi Gessa, ${ }^{1,2}$ and Marco Pistis ${ }^{1,2}$ \\ ${ }^{1}$ Center of Excellence "Neurobiology of Addiction," 2"B. B. Brodie" Department of Neuroscience, and ${ }^{3}$ Consiglio Nazionale delle Ricerche (CNR) Institute of \\ Neuroscience, University of Cagliari, 09042 Monserrato (CA), Italy, ${ }^{4}$ Group Molecular Genetics of Behavior, Max Planck Institute of Psychiatry, 80804 \\ Munich, Germany, and ${ }^{5} \mathrm{CNR}$ Endocannabinoid Research Group, Institute of Biomolecular Chemistry, 80078 Pozzuoli, Italy
}

\begin{abstract}
Endocannabinoids form a novel class of retrograde messengers that modulate short- and long-term synaptic plasticity. Depolarizationinduced suppression of excitation (DSE) and inhibition (DSI) are the best characterized transient forms of endocannabinoid-mediated synaptic modulation. Stimulation protocols consisting of long-lasting voltage steps to the postsynaptic cell are routinely used to evoke DSE-DSI. Little is known, however, about more physiological conditions under which these molecules are released in vitro. Moreover, the occurrence in vivo of such forms of endocannabinoid-mediated modulation is still controversial. Here we show that physiologically relevant patterns of synaptic activity induce a transient suppression of excitatory transmission onto dopamine neurons in vitro. Accordingly, in vivo endocannabinoids depress the increase in firing and bursting activity evoked in dopamine neurons by prefrontal cortex stimulation. This phenomenon is selectively mediated by the endocannabinoid 2-arachidonoyl-glycerol (2-AG), which activates presynaptic cannabinoid type 1 receptors. 2-AG synthesis involves activation of metabotropic glutamate receptors and $\mathrm{Ca}^{2+}$ mobilization from intracellular stores. These findings indicate that dopamine neurons release 2-AG to shape afferent activity and ultimately their own firing pattern. This novel endocannabinoid-mediated self-regulatory role of dopamine neurons may bear relevance in the pathogenesis of neuropsychiatric disorders such as schizophrenia and addiction.
\end{abstract}

Key words: $\mathrm{CB} 1$; dopamine; endocannabinoid; excitatory transmission; midbrain; retrograde signal

\section{Introduction}

Endocannabinoids, released from depolarized neurons, act retrogradely to stimulate cannabinoid type 1 (CB1) receptors located on presynaptic terminals and transiently suppress neurotransmitter release [phenomena termed depolarization-induced suppression of excitation (DSE) and inhibition (DSI)] (for review, see Alger, 2002; Diana and Marty, 2004). DSE-DSI is the first known and best-characterized model of how the endocannabinoid system functions in the brain; however, massive stimulation protocols are routinely used to induce these phenomena (for review, see Alger, 2002; Diana and Marty, 2004). Rather long-lasting voltage steps to the postsynaptic cell are difficult to be regarded as physiological, thus leading to the assumption that endocannabinoid release might occur only during periods of in-

Received Aug. 25, 2004; revised 0ct. 7, 2004; accepted 0ct. 12, 2004.

This work was supported by grants from the Assessorato Igiene e Sanità (Regione Autonoma della Sardegna), COFIN 2003 (Ministero dell'Istruzione, dell'Università e della Ricerca), and Deutsche Forschungsgemeinschaft (LU755/1-3) and by a scholarship from the Hertie Foundation (B.L.). We thank S. Marinelli, M. A. Ungless, and B. Schilstrom for many useful comments on this manuscript, W. T. Dunn III for proofreading this manuscript, B. Wölfel for genotyping, and P. Urbani for synthesizing VDM-11.

${ }^{*} M . M$. and S.P. contributed equally to this work.

Correspondence should be addressed to Miriam Melis, "B. B. Brodie” Department of Neuroscience, University of Cagliari, Cittadella Universitaria, 09042 Monserrato (CA), Italy. E-mail: myriam@unica.it.

DOI:10.1523/JNEUROSCI.3502-04.2004

Copyright $\odot 2004$ Society for Neuroscience ～0270-6474/04/2410707-09\$15.00/0 tense synaptic stimulation (Maejima et al., 2001). Nonetheless, endocannabinoids, produced "on demand" (Di Marzo et al., 1994), are involved in a number of physiological situations spanning from pain perception to cognitive functions (Calignano et al., 1998; Di Marzo et al., 1998; Walker et al., 1999; Lichtman et al., 2002; Lutz, 2002). Therefore, one of the most important challenges is to determine possible physiological modes of DSE-DSI induction. Hence, studies aimed at establishing the physiological patterns of synaptic activity required to induce endocannabinoid release have just started (Brown et al., 2003; Hampson et al., 2003; Fortin et al., 2004; Galante and Diana, 2004).

Dopamine (DA) neurons of the ventral tegmental area (VTA) play a central role in motivation, reward-related behaviors, and cognition (Schultz, 2002). Their spontaneous activity is importantly regulated by excitatory inputs (Kalivas, 1993; Overton and Clark, 1997), the modulation of which appears to be crucial in DA-related functions and disorders (Grace, 1991; Wise, 1996; Schultz, 2002). Endocannabinoids, released by depolarized VTA DA neurons, transiently suppress these inputs through activation of presynaptic CB1 receptors (DSE) (Melis et al., 2004). DSE in the VTA is a $\mathrm{Ca}^{2+}$-dependent phenomenon, enhanced by somatodendritic released DA via activation of postsynaptic $\mathrm{D}_{2} \mathrm{DA}$ receptors; however, DSE in the VTA seems to occur only during prolonged depolarizations, which rarely occur during ongoing 
physiological activity. Indeed, DA cells fire spontaneously at low rates $(0.5-5 \mathrm{~Hz})$ with long-duration action potentials riding on a depolarizing phase ( $>2 \mathrm{msec} ; 3-15 \mathrm{mV}$ ) followed by a pronounced afterhyperpolarization (Grace and Bunney, 1983, 1984). These neurons display a typical firing pattern that is single spiking and/or consisting of bursts of action potentials, the intraburst interspike interval of which is $\sim 60 \mathrm{msec}$ (Grace and Bunney, 1984; Grace and Onn, 1989). Consequently, because endocannabinoids appear to be released by DA cells only on prolonged depolarizations ( $>5 \mathrm{sec}$ ) (Melis et al., 2004), it can be speculated that they might only limit the synaptic drive onto VTA DA neurons to prevent their pathological overexcitation.

Despite widespread interest, the potential physiological significance, and the implications for endocannabinoid-mediated phenomena in the VTA, many questions remain unanswered. First, it is not clear whether endocannabinoids are released from VTA DA cells during more physiological circumstances such as during normal ongoing synaptic activity in vitro. Second, it is not known whether an endocannabinoid-mediated signaling occurs under circumstances encountered physiologically in vivo. Third, it is not known which endocannabinoid is released by VTA DA cells under these conditions.

Ergo, we investigated whether endocannabinoid-mediated retrograde signal could be produced in the VTA during ongoing synaptic activity both in vitro and in vivo.

\section{Materials and Methods}

All experiments were performed in strict accordance with the care and use of animals approved by the American Physiological Society and European Economic Community Council Directive of November 24, 1986 $(86 / 609)$. All efforts were made to minimize pain and suffering and reduce the number of animals used.

\section{In vitro recordings}

The preparation of VTA slices was as described previously (Johnson and North, 1992). Briefly, male Sprague Dawley rats (Harlan Italy, San Pietro al Natisone, Italy) (14-28 d) or CB1 ${ }^{-/-}$and $\mathrm{CB} 1^{+/+}$mice (see below for detailed information) were anesthetized with halothane and killed. A block of tissue containing the midbrain was rapidly dissected and sliced in the horizontal plane (300 and $230 \mu \mathrm{m}$ for rat and mouse slices, respectively) with a Vibratome (Campden Instruments, Lafayette, IN) in icecold low- $\mathrm{Ca}^{2+}$ solution containing (in $\mathrm{mm}$ ): $126 \mathrm{NaCl}, 1.6 \mathrm{KCl}, 1.2$ $\mathrm{NaH}_{2} \mathrm{PO}_{4}, 1.2 \mathrm{MgCl}_{2}, 0.625 \mathrm{CaCl}_{2}, 18 \mathrm{NaHCO}_{3}$, and 11 glucose. Slices (three per animal) were transferred to a holding chamber with artificial $\mathrm{CSF}(\mathrm{ACSF})\left(37^{\circ} \mathrm{C}\right)$ saturated with $95 \% \mathrm{O}_{2}$ and $5 \% \mathrm{CO}_{2}$ containing (in $\mathrm{mm}): 126 \mathrm{NaCl}, 1.6 \mathrm{KCl}, 1.2 \mathrm{NaH}_{2} \mathrm{PO}_{4}, 1.2 \mathrm{MgCl}_{2}, 2.4 \mathrm{CaCl}_{2}, 18$ $\mathrm{NaHCO}_{3}$, and 11 glucose. Slices were allowed to recover for at least $1 \mathrm{hr}$ before being placed, as hemislices, in the recording chamber and superfused with the ACSF $\left(37^{\circ} \mathrm{C}\right)$ saturated with $95 \% \mathrm{O}_{2}$ and $5 \% \mathrm{CO}_{2}$. Cells were visualized with an upright microscope with infrared illumination (Axioskop FS 2 plus; Zeiss, Oberkochen, Germany), and whole-cell voltage-clamp recordings were made by using an Axopatch 200B amplifier (Axon Instruments, Foster City, CA). For BAPTA experiments, EPSC recordings were made with electrodes filled with a solution containing (in mM): $117 \mathrm{Cs}$ methansulfonic acid, $20 \mathrm{HEPES}, 15 \mathrm{Cs}_{4}$-BAPTA, 0.4 EGTA, $2.8 \mathrm{NaCl}$, 5 TEA-Cl, $2.5 \mathrm{Mg}_{2}$ ATP, and $0.25 \mathrm{Mg}_{2} \mathrm{GTP}$, pH 7.2-7.4, 275-285 mOsm. All other EPSC recordings were made with electrodes filled with a solution containing (in mM): 117 Cs methansulfonic acid, 20 HEPES, 0.4 EGTA, $2.8 \mathrm{NaCl}, 5$ TEA-Cl, $2.5 \mathrm{Mg}_{2} \mathrm{ATP}$, and $0.25 \mathrm{Mg}_{2} \mathrm{GTP}$, pH 7.2-7.4, 275-285 mOsm. Picrotoxin ( $100 \mu \mathrm{M})$ was added to the ACSF for recording to block $\mathrm{GABA}_{\mathrm{A}}$ receptor-mediated IPSCs. Experiments were begun only after series resistance had stabilized (typically 15-40 $\mathrm{M} \Omega$ ). Series and input resistance were monitored continuously on-line with a $5 \mathrm{mV}$ depolarizing step $(25 \mathrm{msec})$. Data were filtered at $2 \mathrm{kHz}$, digitized at $10 \mathrm{kHz}$, and collected on-line with acquisition software (pClamp 8.2; Axon Instruments). DA neurons from the anterior VTA were identified by the presence of a large $I_{\mathrm{h}}$ current (Johnson and North,
1992) that was assayed immediately after break-in, using a series of incremental $10 \mathrm{mV}$ hyperpolarizing steps from a holding potential of -70 $\mathrm{mV}$. A bipolar stainless steel stimulating electrode (FHC, Bowdoinham, $\mathrm{ME}$ ) was placed $100 \mu \mathrm{m}$ rostral to the recording electrode and used to stimulate at a frequency of $0.1 \mathrm{~Hz}$. AMPA-mediated EPSCs were recorded at $-70 \mathrm{mV}$. The amplitudes of AMPA EPSCs were calculated by taking a $1 \mathrm{msec}$ window around the peak of the EPSC and comparing this with the $5 \mathrm{msec}$ window immediately before the stimulation artifact. Paired stimuli were given with an interstimulus interval of $50 \mathrm{msec}$, and the ratio between the second and first EPSCs was calculated and averaged for a $5 \mathrm{~min}$ baseline. The magnitude of suppression of excitation (SE) was measured as percentage of the mean amplitude of consecutive EPSCs after the train $(5 \mathrm{~Hz}, 10$ stimuli; acquired between 5 and $15 \mathrm{sec}$ after the end of the train) relative to that of five EPSCs before the train (Melis et al., 2004). All numerical data are given as mean \pm SEM. Each slice received only a single drug exposure. Averaged data from different experiments are presented as mean \pm SEM. Statistical significance was assessed using one- or two-way ANOVA for repeated measures followed by either Dunnett's or $t$ test, where appropriate.

\section{In vivo recordings}

Animals were anesthetized with urethane ( $1.5 \mathrm{gm} / \mathrm{kg}$, i.p.), their femoral vein was cannulated for intravenous administration of pharmacological agents, and they were placed in the stereotaxic apparatus (Kopf, Tujunga, CA) with their body temperature maintained at $37 \pm 1^{\circ} \mathrm{C}$ by a heating pad. Thereafter, the scalp was retracted, and one burr hole was drilled above the VTA [anteroposterior (AP), $+2.0 \mathrm{~mm}$ from $\lambda$; lateral $(\mathrm{L})$, $0.3-0.6 \mathrm{~mm}$ from midline] for the placement of a recording electrode. An additional hole was drilled for the placement of a Formvar-coated stimulating stainless steel bipolar electrode ( $250 \mu \mathrm{m}$ tip diameter) above the ipsilateral medial prefrontal cortex (PFC) $[\mathrm{AP},+3.0 \mathrm{~mm}$ from breg$\mathrm{ma}$;, $1.0 \mathrm{~mm}$ from the midline; ventral $(\mathrm{V}), 2.0 \mathrm{~mm}$ from the cortical surface] for orthodromic stimulation of VTA DA neurons. Structures were localized according to the stereotaxic atlas of Paxinos and Watson (1997). Single-unit activity of neurons located in VTA (V, 7.2-8.0 mm from the cortical surface) was recorded extracellularly with glass micropipettes filled with $2 \%$ Pontamine sky blue dissolved in $0.5 \mathrm{~m}$ sodium acetate (impedance, 2-5 M $\Omega$ ). Single-unit activity was filtered (bandpass, $500-5000 \mathrm{~Hz}$ ), and individual spikes were isolated by means of a window discriminator (Digitimer, Hertfordshire, UK), displayed on a digital storage oscilloscope (TDS 3012; Tektronix, Marlow, UK), and recorded by a VCR. Experiments were sampled on-line and off-line by a computer connected to CED 1401 interface (Cambridge Electronic Design, Cambridge, UK). Recording electrodes were lowered slowly into the VTA via a micromanipulator (Narishige, Tokyo, Japan). Single units were isolated and identified according to previously published criteria (Guyenet and Aghajanian, 1978; Grace and Bunney, 1983, 1984). Bursts were defined as the occurrence of two spikes at an interspike interval $<80$ msec and terminated when the interspike interval exceeded $160 \mathrm{msec}$ (Grace and Bunney, 1984). Neurons that responded to PFC stimulation were identified according to previously published criteria (Tong et al., 1996a). Briefly, two main populations of DA neurons could be identified: neurons that displayed an inhibitory response shortly after the stimulus, followed by an excitation (IE responses), and cells that displayed an excitation usually, but not necessarily, followed by an inhibition (E responses). In this study we selected DA neurons with E responses, because the enhanced spiking probability is time-locked to the stimulus and was previously demonstrated to be dependent on released glutamate (Tong et al., 1996b). Baseline firing rates were obtained for at least $3 \mathrm{~min}$, and then the stimulator was switched on $(0.25-0.5 \mathrm{~mA}$ at $1 \mathrm{~Hz})$ and kept on throughout the experimental session. Drugs were administered intravenously at exponentially increasing doses. After each dose, evoked neuronal activity was recorded for a minimum of 4 min before a subsequent administration occurred. Only one cell was recorded per rat. For each neuron, peristimulus time histograms (PSTHs) of spiking activity were generated, and burst analysis was performed using the Spike 2 software (CED, Cambridge, UK), according to criteria published previously by Tong et al. (1996b).

PSTHs of spiking activity were generated using bins of $50 \mathrm{msec}(1 \mathrm{sec}$ 
sweeps; 20 bins), and neuronal activity was recorded for least 4 min. Stimulus-evoked spiking probability was calculated by dividing the number of spikes in the 3 consecutive bins after the stimulus ( $150 \mathrm{msec}$ ) by the total number of spikes in all 20 bins $(1 \mathrm{sec})$.

Burst analysis was also performed on neuronal activity induced by PFC stimulation. For this purpose, PSTHs were compiled (with $100 \mathrm{msec}$ bins; 1 sec sweeps; 10 bins) that combined the burst onset data for all cells in the study. According to previous studies (Tong et al., 1996a,b), this analysis revealed that a large number of bursts were temporally associated with the occurrence of stimuli. Stimulus-evoked burst probability was calculated by dividing the number of bursts occurring within 3 consecutive bins after the stimulus ( $300 \mathrm{msec}$ ) by the total number of bursts in all 10 bins $(1 \mathrm{sec})$. Drug-induced changes in spike or burst probability were normalized to the pre-drug baseline levels.

At the end of each recording section, DC current (10 $\mu \mathrm{A}$ for $15 \mathrm{~min})$ was passed through the recording electrode to eject Pontamine sky blue, which allowed the identification of the recorded cells. Brains were removed and fixed in $8 \%$ formalin solution. The position of the electrodes was microscopically identified on serial sections $(60 \mu \mathrm{m})$ stained with cresyl violet.

Data were always normalized to pre-drug baseline levels and analyzed using one-way ANOVA. Post hoc multiple comparisons were made using the Dunnett's test.

\section{CB1 receptor knock-out mice}

CB1 receptor knock-out mice were generated as described previously (Marsicano et al., 2002). Homozygous mutant mice (CB1 ${ }^{-/-}$) and wildtype $\left(\mathrm{CB} 1^{+/+}\right)$littermates derived from heterozygous matings were genotyped as described (Marsicano et al., 2002). In the present study, juvenile mutant male mice aged between 3 and 5 weeks were used. Animals were housed in groups under standard laboratory conditions $(12 \mathrm{hr}$ light/dark cycle) with food and water available ad libitum. In all cases, the experimenter was blind to the genotype.

\section{Pharmacology}

WIN55,212-2 (WIN), AM281, ( \pm )-amino-4-carboxy-methylphenylacetic acid (MCPG), 7-(hydroxyimino)cyclopropa[b]chromenla-carboxylate ethyl ester (CPCCOEt), 2-methyl-6-(phenylethynyl)pyridine (MPEP), thapsigargin, and ruthenium red were purchased from Tocris Cookson (Bristol, UK). Ryanodine and other chemicals were purchased from Sigma Aldrich (St. Louis, MO). OMDM-2, VDM-11, and tetrahydrolipstatin (THL) were provided by Dr. V. Di Marzo (Endocannabinoid Research Group, Institute of Biomolecular Chemistry, Pozzuoli, Italy). SR141716A (SR) was a generous gift from Dr. G. Le Fur (Sanofi Research, Libourne, France).

In vitro recordings. For extracellular application, drugs were applied in known concentrations to the superfusion medium. For intracellular application, drugs were applied in known concentrations to the internal solution. All the drugs were dissolved in DMSO. The final concentration of DMSO was $<0.01 \%$.

In vivo recordings. WIN and SR were emulsified in $1 \%$ Tween 80 and then diluted in saline solution and sonicated. Injection volume was 1 $\mathrm{ml} / \mathrm{kg}$ body weight.

\section{Results \\ A brief train elicits endocannabinoid-mediated suppression of excitation in vitro}

We first asked whether a brief train of stimuli could induce transient suppression of excitation under physiological conditions in vitro. We recorded from VTA DA cells in rat midbrain slices in a whole-cell clamp configuration at $37^{\circ} \mathrm{C}$. Rostral fibers were activated with the following stimulus pattern: $0.1 \mathrm{~Hz}$ stimulation preceded and followed a train of 10 stimuli at $5 \mathrm{~Hz}$ (Fig. $1 A$ ). This brief $(2 \mathrm{sec})$ train transiently decreased the amplitude of EPSCs (Fig. 1A) (EPSC amplitude $61.3 \pm 4.3 \%$ of baseline; $n=7 ; p<$ $0.0001)$. This effect was accompanied by an increased pairedpulse ratio (Fig. $1 B$ ) (basal $1.2 \pm 0.1$ vs SE $2.0 \pm 0.2 ; n=7 ; p<$ $0.005)$, indicating a presynaptic locus of action. We next tested the sensitivity of this phenomenon by varying the number of stimuli and their frequency. We first varied the number of stimuli while maintaining the frequency at $5 \mathrm{~Hz}$. The magnitude of suppression of excitation saturated at five pulses (Fig. 1C) $(n=7)$. Therefore, we maintained this number of stimuli constant and varied the stimulation frequency. We chose a range of frequencies that mimic the physiological modes of PFC neuronal activation in vivo (Jackson et al., 2001), which represents a major excitatory afferent to the VTA (Christie et al., 1985; Kalivas, 1993; Overton and Clark, 1997). Figure $1 C$ shows the frequency dependence of train-induced suppression of EPSCs $(n=5)$. The positive correlation between suppression of excitation induced by a depolarizing step (DSE: voltage step to $+40 \mathrm{mV}, 10 \mathrm{sec}$ ) and the brief train (SE) suggested that the underlying mechanism(s) is similar and involves endocannabinoids (Melis et al., 2004) (Fig. 1D) $\left(r^{2}=\right.$ $0.87 ; p<0.005)$. We therefore asked whether activation of presynaptic CB1 receptors was responsible for this phenomenon, as we had shown previously for DSE in the VTA (Melis et al., 2004). Incubating slices with the CB1 receptor antagonist AM281 (500 $\mathrm{nM}$ ) abolished suppression of excitation induced by the brief train (Fig. $1 E$ ) (EPSC amplitude $119.7 \pm 11.1 \%$ of baseline; $n=6 ; p<$ 0.001 vs control). In addition, the synthetic CB1 receptor agonist WIN $(1 \mu \mathrm{M})$, which acutely depresses excitatory transmission onto VTA DA cells (Melis et al., 2004), occluded suppression of excitation induced by the brief train (Fig. $1 E$ ) (EPSC amplitude $101.2 \pm 3.9 \%$ of baseline; $n=5 ; p<0.001$ vs control). Although CB1 receptors are so far the only cloned cannabinoid receptor type in the CNS (Matsuda et al., 1990), increasing evidence suggests the existence of novel cannabinoid receptors, in addition to the cloned G-protein-coupled CB1 and CB2 (Jarai et al., 1999; Di Marzo et al., 2000; Hajos et al., 2001; Hajos and Freund, 2002a,b; Fride et al., 2003). Therefore, we used $\mathrm{CB}^{-1-}$ mice (Marsicano et al., 2002) to determine whether this endocannabinoidmediated suppression of excitation is indeed mediated by activation of CB1 receptors. Train-induced suppression of excitation was normal in $\mathrm{CB} 1^{+/+}$mice (EPSC amplitude $51.2 \pm 2.9 \%$ of baseline; $n=5$; $p<0.001$ ) (Fig. $1 E$ ) and comparable with that observed in midbrain slices from juvenile rats (Fig. $1 A$ ). Conversely, it was totally absent in $\mathrm{CB} 1^{-1-}$ mice (EPSC amplitude $104.8 \pm 8.7 \%$ of baseline; $n=5 ; p<0.001$ vs CB1 $^{+/+}$) (Fig. $1 E$ ). These results showed that during ongoing synaptic activity, VTA DA neurons produce endocannabinoids that, diffusing retrogradely, activate solely CB1 receptors located on presynaptic terminals and suppress glutamate release.

\section{Prefrontal stimulation of VTA DA cells elicits endocannabinoid-mediated suppression of excitation in vivo} Thus far, the importance of an endocannabinoid retrograde signal occurring within the range of physiologically in vivo firing patterns has been questioned because no supportive evidence subsists in vivo (Hampson et al., 2003). Therefore, in an attempt to investigate whether this endocannabinoid-dependent suppression of excitation is a physiologically relevant phenomenon in vivo, we studied the responses of VTA DA neurons to electrical stimulation of the medial PFC. According to previous studies, two main types of responses were observed in DA neurons: bimodal excitatory responses followed by transient inhibition or inhibitory responses followed by excitation (Tong et al., 1996a). We studied neurons with initial excitatory responses because the enhanced spiking activity is time locked to the stimulus, which is temporally related to release of glutamate in VTA (Tong et al., 1996b). If endocannabinoids are released under these circumstances, they would dampen PFC-evoked responses. As pre- 
dicted, the CB1 antagonist SR (1.25-5.0 $\mathrm{mg} / \mathrm{kg}$, i.v.) dose-dependently increased firing responses (in 10 of $12 \mathrm{DA}$ neurons) elicited by PFC stimulation (maximum enhancement of stimulus-locked spiking probability: $122.3 \pm 9.7 \%$ at SR $5.0 \mathrm{mg} / \mathrm{kg}$; $n=10 ; p<0.01$ ) (Fig. $2 A-C$ ). This augmented excitability was paralleled by an enhanced PFC-induced bursting activity. The probability of inducing stimuluslocked bursts was increased to $209.7 \pm$ $52 \%$ of baseline at SR $5.0 \mathrm{mg} / \mathrm{kg}(n=6$; $p<0.05$ ) (Fig. 2C) and so was the frequency of spikes within bursts (intraburst frequency, $114.3 \pm 5.6 \%$ of baseline; $n=$ 6; $p<0.05$ ) (Fig. 2C). Conversely, WIN administration $(0.125-0.25 \mathrm{mg} / \mathrm{kg}$, i.v.) dose-dependently decreased spiking probability $(65.0 \pm 7.7 \%$ of baseline level at $0.25 \mathrm{mg} / \mathrm{kg} ; n=6$; $p<0.05$ ) (Fig. $3 A-C$ ), stimulus-locked burst probability (41.6 \pm $10.7 \%$ of control at $0.25 \mathrm{mg} / \mathrm{kg} ; n=4 ; p<$ 0.05 ) (Fig. 3C), and intraburst frequency $(49.1 \pm 5.46 \%$ at WIN $0.25 \mathrm{mg} / \mathrm{kg} ; n=4$; $p<0.01$ ) (Fig. 3C). Importantly, WINinduced effects were fully reversed by SR $(2.5 \mathrm{mg} / \mathrm{kg}$, i.v.) (Fig. $3 A-C)$. We then tested VDM-11, an endocannabinoid transporter inhibitor (Bisogno et al., 2001). Intravenous administration of VDM-11 $(2.0 \mathrm{mg} / \mathrm{kg})$ did not significantly affect stimulus-evoked responses in DA neurons (spiking probability $101.4 \pm$ $6.7 \%$ and burst probability $93.6 \pm 11.6 \%$ of baseline; $n=5$; data not shown).

\section{2-Arachidonoyl-glycerol is the retrograde messenger for suppression of excitation}

Endocannabinoids are substrates for a putative membrane transporter, the activity of which regulates their life span in the extracellular space as well as their delivery outside the cell membrane (Di Marzo et al., 1994; Beltramo et al., 1997; Piomelli et al., 1999). Using the recording electrode, we filled the postsynaptic cell with OMDM-2 $(5 \mu \mathrm{M})$, an inhibitor of endocannabinoid transporter (Ortar et al., 2003), and observed that no depression could be induced after the brief train (Fig. $4 A$ ) (EPSC amplitude $107.3 \pm 8.9 \%$ of baseline; $n=5 ; p<0.001$ vs control). This result implies that suppression of excitation does not occur when endocannabinoid release is disrupted. 2-AG, the most abundant endocannabinoid in tissues (Mechoulam et al., 1995; Sugiura et al., 1995; Stella et al., 1997), is released from diacylglycerols (DAGs) by a recently cloned $s n$-1-DAG lipase (Bisogno et al., 2003). DAGs in turn are produced, among other mechanisms, from the activation of the phosphatidylinositol-specific phospholipase C (PI-PLC) (Stella et al., 1997; Di Marzo et al., 1998). To understand whether, and to what extent of the known endocannabinoids (Di Marzo et al.,

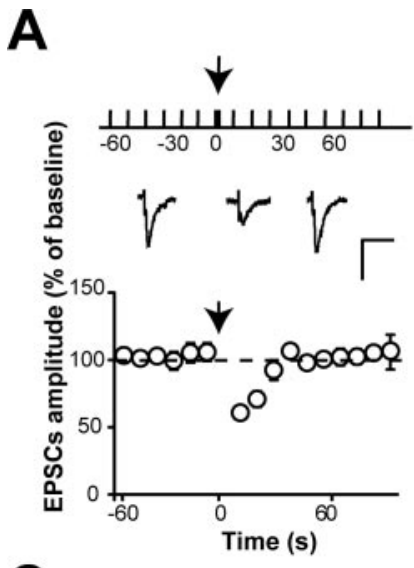

B
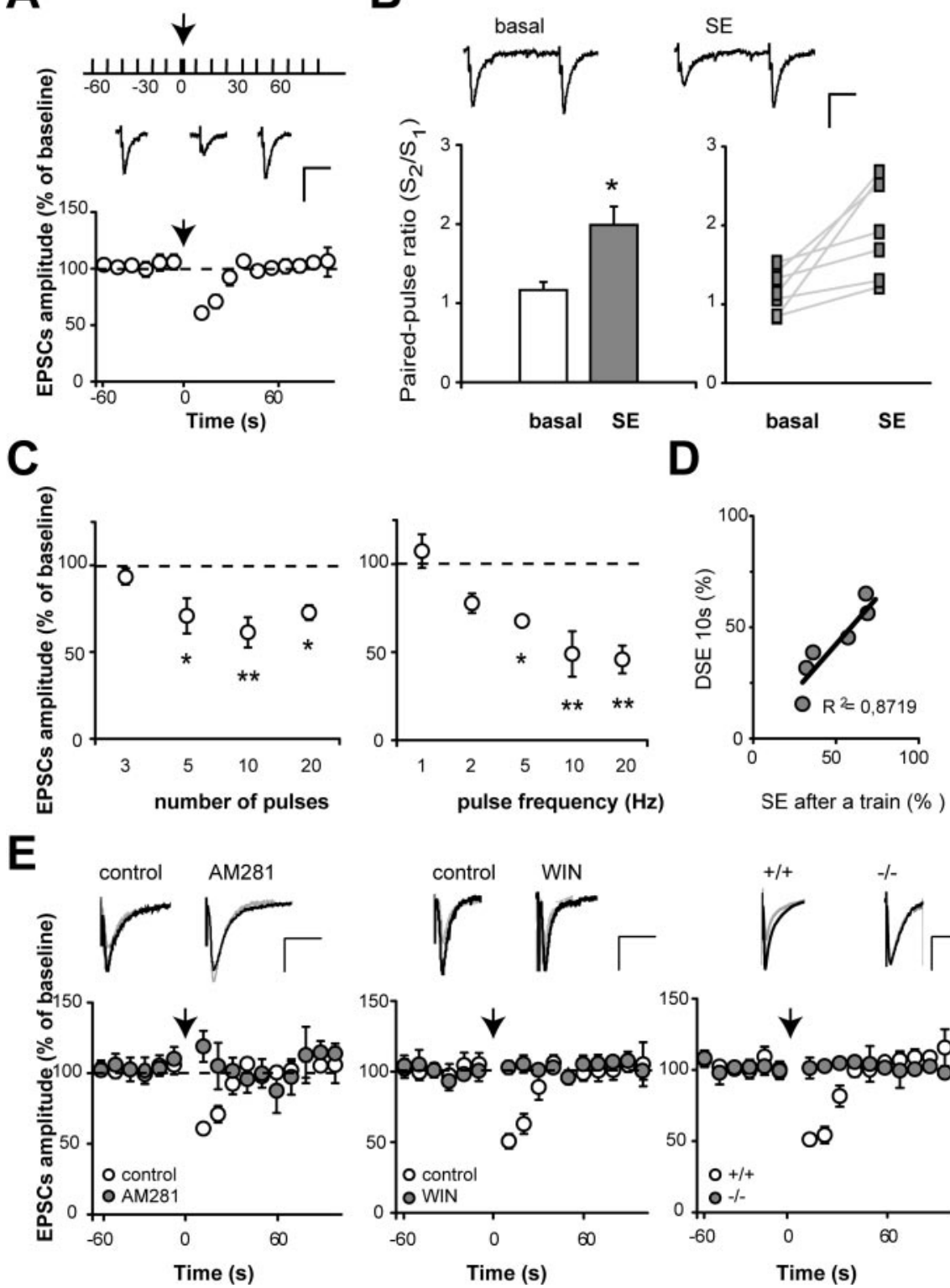

Figure 1. A brief train inhibits EPSCs through activation of $C B 1$ receptors. A, VTA DA cells, stimulated by low-frequency stimulation $(0.1 \mathrm{~Hz})$, respond to a train (10 stimuli; $5 \mathrm{~Hz}$ ) at time 0 (arrow) with a transient SE. Time course of train-induced SE $(n=$ 7) is shown. Representative traces for each condition from a single experiment are shown. Calibration: $20 \mathrm{msec}, 100 \mathrm{pA} . \mathrm{B}$, Train-induced SE increases paired-pulse ratio $(n=7 ; p<0.005)$. The left graph plots the averaged paired-pulse ratio in a bar graph form, and the right graph plots the paired-pulse ratio for each of the experiments in $A$ before (basal) and $5-15$ sec after (SE) the train. $C$, SE induction depends on number of pulses within the train $\left(n=7 ;{ }^{*} p<0.05 ;{ }^{* *} p<0.01\right)$ and on stimulation frequency $\left(n=5 ;{ }^{*} p<0.05 ;{ }^{* *} p<0.01\right)$. D , The magnitude of DSE induced by a depolarizing step (voltage step to $+40 \mathrm{mV} ; 10$ $\mathrm{sec})$ is plotted as a function of train-evoked $\mathrm{SE}(n=6)$. Data are fit by linear regression with $r^{2}=0.87(p<0.005)$. $E$, In the presence of either AM281 (left panel, closed circles; $n=6$ ) or WIN (middle panel, closed circles; $n=5$ ), SE could not be induced. Time course of train-induced SE (control, open circles) is shown. Train-induced suppression of excitation is absent in the $\mathrm{CB}^{-1-}$ mice (right panel; $n=5)$. Averaged time courses of SE in the $\mathrm{CB} 1^{+/+}$(open symbols; $\left.n=5\right)$ and $\mathrm{CB} 1^{-1-}$ (closed symbols; $n=$ 5) mice are displayed. Representative traces for each condition from a single experiment are shown. The EPSC recorded after the train is superimposed in light gray for comparison. Calibration: $20 \mathrm{msec}$, $100 \mathrm{pA}$.

1998), 2-AG contributes to suppression of excitation, we filled the postsynaptic cell with THL (500 nM) or bath applied U73122 $(5 \mu \mathrm{M})$, inhibitors of $s n-1-D A G$ lipase and PI-PLC activity, respectively (Stella et al., 1997; Bisogno et al., 2003). THL completely prevented the train-induced effect on EPSC amplitude (Fig. $4 A, C$ ) (EPSC amplitude $116.4 \pm 7.8 \%$ of baseline; $n=7$; $p<0.001$ vs control). A similar although not comparable result was obtained when slices were perfused with U73122 (Fig. 4B,C) 
A
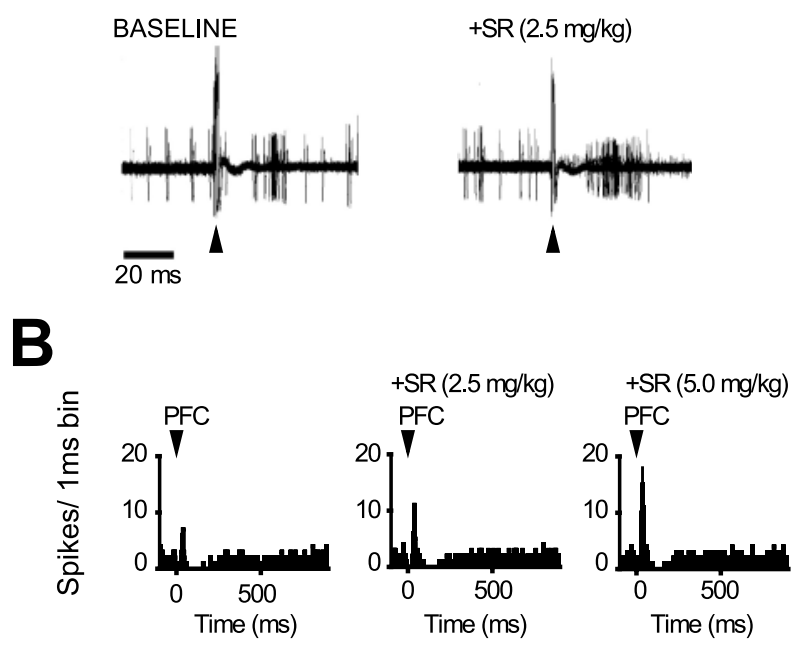

C
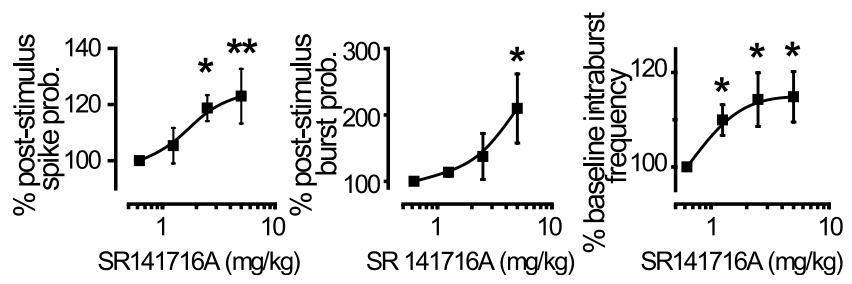

Figure 2. Blockade of $C B 1$ receptors enhances $D A$ neuron responses to $P F C$ stimulation. $A, B$, Representative digital storage oscilloscope traces $(A)$ and peristimulus time histograms $(B)(1$ msec bin) illustrating excitatory responses in VTA DA neurons evoked by the stimulation of the PFC at time 0 (arrows) and the increase in spiking probability after the intravenous administration of SR.C, The probability of stimulus-locked spikes (left), bursts (middle), and the frequency of spikes within bursts (right) is increased in DA neurons after SR administration. Data are expressed as mean \pm SEM and normalized to their baseline level $(100 \%) .{ }^{*} p<0.05 ;{ }^{* *} p<$ 0.01 ; ANOVA and Dunnett's test.

(EPSC amplitude $90.2 \pm 5.8 \%$ of baseline; $n=7 ; p<0.001$ vs control), which per se was ineffective. These results indicate that $2-\mathrm{AG}$ is the retrograde messenger for train-induced suppression of excitation at these synapses. Remarkably, given the significant difference between the effects produced by THL and U73122 (Fig. $4 C)(p<0.01)$, we cannot rule out the possibility that $2-\mathrm{AG}$ synthesis might also occur through an alternative PI-PLCindependent pathway (Bisogno et al., 1999a).

In the VTA, DSE requires postsynaptic $\mathrm{Ca}^{2+}$ elevation (Melis et al., 2004). Similarly, the perfusion of BAPTA (15 mM) in the intracellular compartment blocked suppression of excitation after the brief train (Fig. 5A) (EPSCs amplitude $105.7 \pm 11.1 \%$ of baseline; $n=7 ; p<0.001$ vs control). This observation indicates that this endocannabinoid-mediated suppression of excitation also requires a postsynaptic rise in intracellular $\mathrm{Ca}^{2+}$. Additionally, filling the postsynaptic cell with thapsigargin $(10 \mu \mathrm{M})$ to inhibit the $\mathrm{Ca}^{2+}$ ATPase and deplete both $\mathrm{IP}_{3}$ - and ryanodinesensitive intracellular $\mathrm{Ca}^{2+}$ stores prevented train-induced suppression of excitation (Fig. 5A) (thapsigargin: EPSC amplitude $102.6 \pm 3.2 \%$ of baseline; $n=7 ; p<0.001$ vs control). Next, filling the postsynaptic cell with either ruthenium red or ryanodine to antagonize ryanodine-sensitive receptors blocked traininduced suppression of excitation (ruthenium red: EPSC amplitude $92.1 \pm 4.5 \%$ of baseline; $n=7 ; p<0.001$ vs control; ryanodine: EPSC amplitude $101 \pm 4.4 \%$ of baseline; $n=7 ; p<$
A
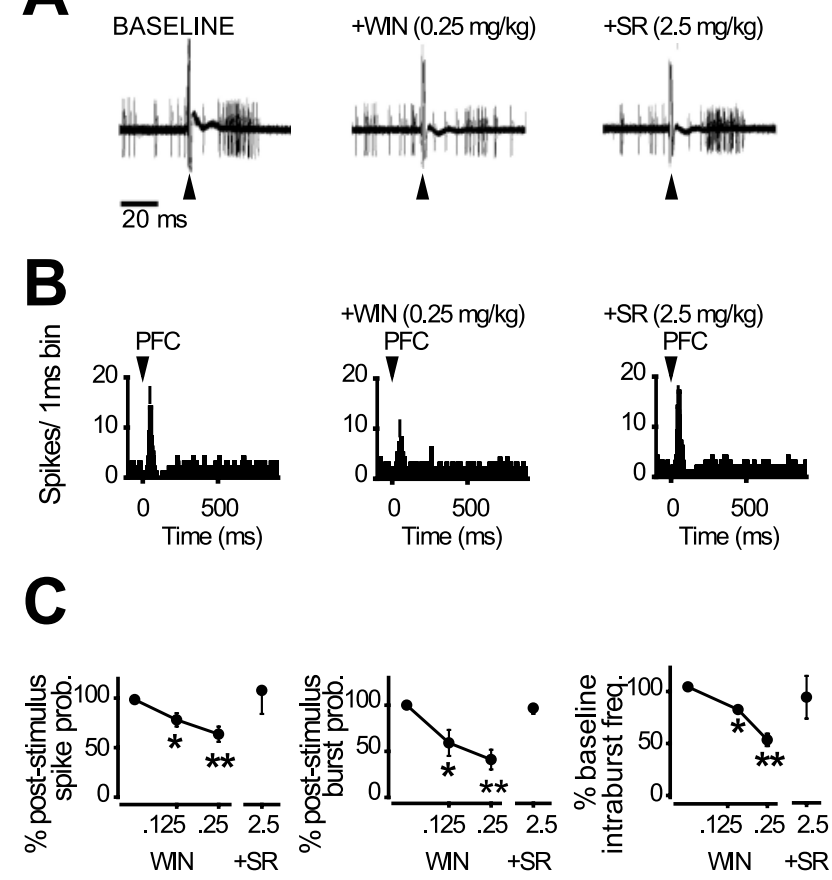

Figure 3. Stimulation of $C B 1$ receptors depresses $D A$ neuron responses to $P F C$ stimulation. $A$, $B$, Representative digital storage oscilloscope traces $(A)$ and peristimulus time histograms $(B)$ (1 msec bin) illustrating excitatory responses in VTA DA neurons evoked by the stimulation of the PFC at time 0 (arrows) and displaying the decrease in stimulation-evoked responses induced by the cannabinoid agonist WIN and the reversal by SR. C, WIN decreases spiking probability of DA neurons after PFC stimulation (left), stimulus-locked bursts (middle), and intraburst frequency (right). All effects were fully reversed by SR. Data are expressed as mean \pm SEM and normalized to their baseline level $(100 \%) .{ }^{*} p<0.05 ;{ }^{* *} p<0.01$; ANOVA and Dunnett's test.

0.001 vs control). Conversely, bath application of EGTA ( $5 \mathrm{mM})$, a $\mathrm{Ca}^{2+}$ chelator that reduces the concentration of extracellular $\mathrm{Ca}^{2+}$, did not prevent induction of suppression of excitation (Fig. 5A) (EPSC amplitude $69.0 \pm 10.3 \%$ of baseline; $n=7 ; p>$ 0.05 vs control). These results suggest that $\mathrm{Ca}^{2+}$ mobilization from intracellular stores, rather than entry through voltage-gated $\mathrm{Ca}^{2+}$ channels, plays a more important role in this phenomenon.

Which receptor is triggering train-induced suppression of excitation? Glutamate mediates fast excitatory transmission via ionotropic receptors, and slow excitatory-inhibitory actions via metabotropic receptors. Ionotropic and metabotropic glutamate receptors (mGluRs) might trigger endocannabinoid production and cause retrograde signaling at these synapses. Indeed, synaptic activation of ionotropic glutamate and/or group I mGluRs triggers endocannabinoid release in several brain regions (Stella et al., 1997; Maejima et al., 2001; Varma et al., 2001; Ohno-Shosaku et al., 2002; Robbe et al., 2002; Brown et al., 2003; Chevaleyre and Castillo, 2003; Galante and Diana, 2004). Perfusion of AP5 (50 $\mu \mathrm{M})$, a competitive NMDA receptor antagonist, did not affect either train-induced suppression of excitation (Fig. 5B) (EPSC amplitude $64.7 \pm 5.8 \%$ of baseline; $n=7 ; p>0.05$ vs control) or basal synaptic transmission (data not shown), suggesting the lack of involvement of these receptors. Because of the limitations of the electrophysiological approach, we were unable to assess the contribution of AMPA receptors to endocannabinoid release. In fact, blocking AMPA receptors with CNQX (10 $\mu \mathrm{M})$ eliminates the EPSCs and makes it impossible to assess any retrograde suppression of excitation (data not shown). Group I mGluRs stimulate PLC activity and release $\mathrm{Ca}^{2+}$ from intracellular stores in 

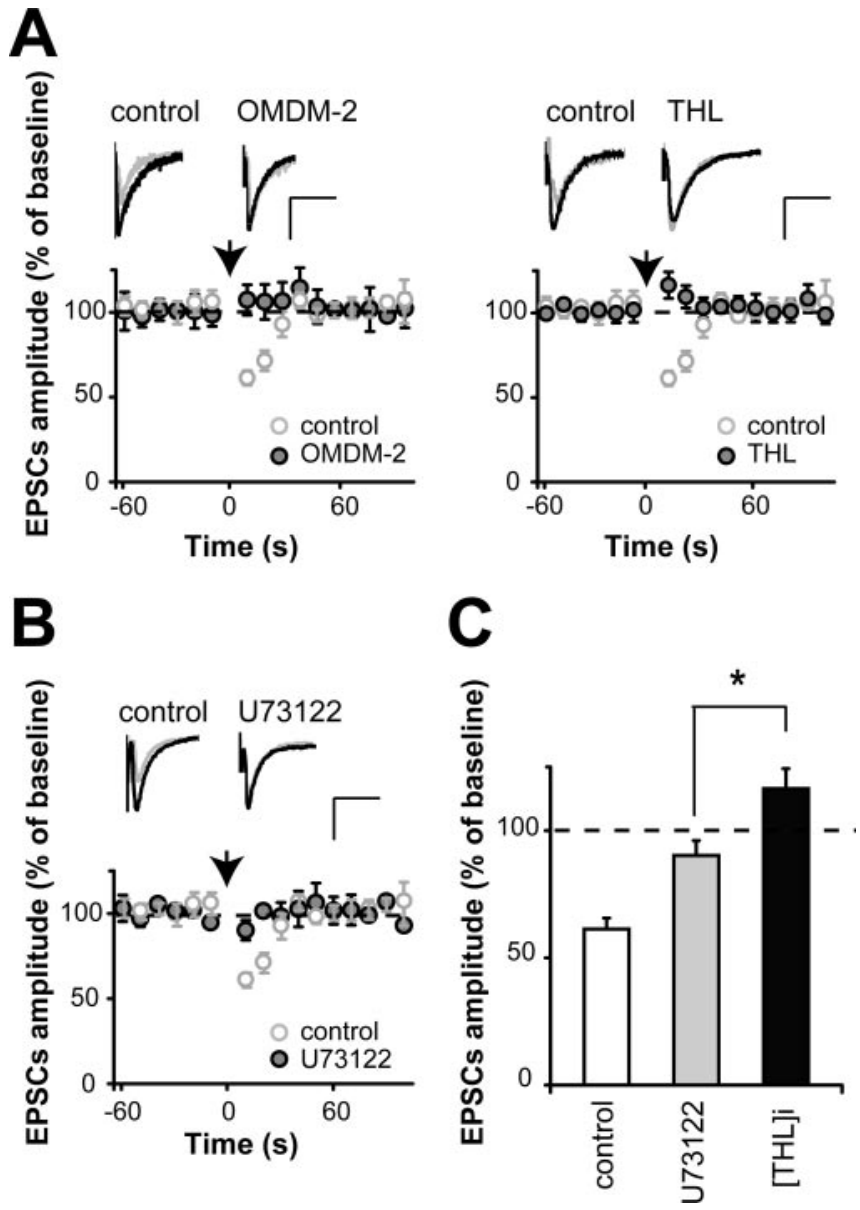

Figure 4. Synthesis and release of 2-AG are necessary for train-induced SE. A, Time course of train-induced SE under normal conditions (open circles; $n=7$ ) and in the presence of OMDM-2 (left, closed circles; $n=5 ; p<0.01$ ) or THL (right, closed circles; $n=7 ; p<0.001$ ). B, Time course of train-induced SE under normal conditions (open circles; $n=7$ ) and in the presence of U73122 (closed circles; $n=7 ; p<0.001$ ). C, Magnitude of EPSC amplitude after the train for THL and U73122 plotted as the percentage of baseline before the train $(n=7 ; p<0.01)$.

many types of neurons, including VTA DA neurons (Morikawa et al., 2003). Thus, it was reasonable to hypothesize their contribution to suppression of excitation via stimulation of one or both of these signaling pathways. Therefore, we perfused the slices with MCPG (1 mM), a broad-spectrum mGluR antagonist, which dramatically attenuated the effect produced by the train (Fig. $5 B$ ) (EPSC amplitude $83.7 \pm 4.3 \%$ of baseline; $n=7 ; p<0.002$ vs control). Midbrain DA cells express group I mGluRs on their soma and dendrites (Kosinski et al., 1998). mGluR1 and mGluR5 subtypes belong to group I mGluRs; therefore, to differentiate between these two subtypes, we bath applied CPCCOEt $(100 \mu \mathrm{M})$ and MPEP $(10 \mu \mathrm{M})$, selective mGluR1 and mGluR5 antagonists, respectively. CPCCOEt fully blocked train-induced suppression of excitation (Fig. $5 B$ ) (EPSC amplitude $94.4 \pm 7 \%$ of baseline; $n=6 ; p<0.001$ vs control), whereas MPEP was ineffective (Fig. $5 B$ ) (EPSC amplitude $67.6 \pm 6.3 \%$ of baseline; $n=6 ; p>0.05$ vs control). Together, these results indicate that the mGluR1 subtype triggers endocannabinoid-mediated suppression of excitation. Last, we found previously that DA acts as a potent enhancer of endocannabinoid release from VTA DA cells through activation of $\mathrm{D}_{2} \mathrm{DA}$ receptors (Melis et al., 2004); however, application of eticlopride (100 nM), a $\mathrm{D}_{2} \mathrm{DA}$ antagonist, failed to affect traininduced suppression of excitation (Fig. 5B) (EPSC amplitude $71.9 \pm 7.3 \%$ of baseline; $n=8 ; p>0.1$ vs control).
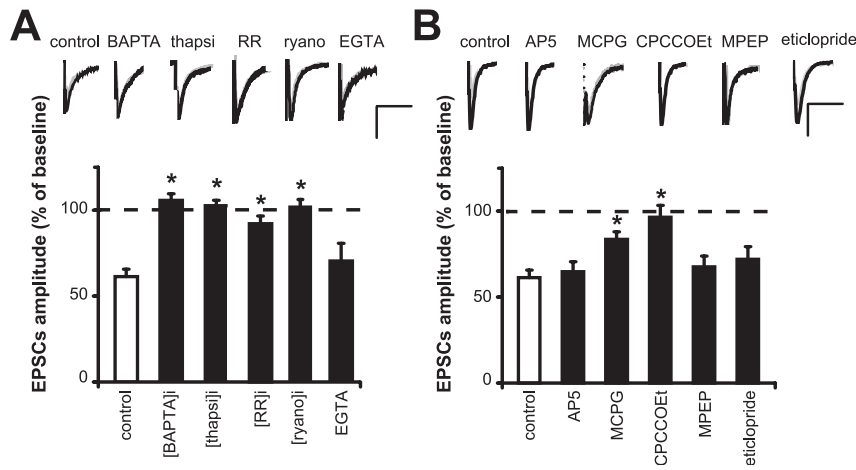

Figure 5. Contribution of intracellular calcium, glutamate, and $D_{2} D A$ receptors to 2-AGinduced effects. $A$, Magnitude of EPSC amplitude after the train for all conditions [thapsigargin (thapsi); ruthenium red (RR); ryanodine (ryano); $n=7$ ] plotted as the percentage of baseline before the train (dotted line). $B$, Magnitude of EPSC amplitude after the train for all conditions (AP5, $n=7$; MCPG, $n=7$; CPCCOEt, $n=6$; MPEP, $n=6$; eticlopride, $n=7$ ) plotted as the percentage of baseline before the train (dotted line). Representative traces for each condition from a single experiment are shown. The EPSC recorded after the train is superimposed in light gray for comparison. Calibration: $20 \mathrm{msec}, 100 \mathrm{pA}$.

\section{Discussion}

The major finding of the present study is that the endocannabinoid system provides a mechanism for a VTA DA cell to shape its own excitatory synaptic inputs both in vitro and in vivo. This "on demand" activation of the endocannabinoid system might represent one of the coinciding events to guarantee a precise physiological regulation of the firing pattern of VTA DA neurons.

We found that a brief burst of synaptic activity induces suppression of excitatory transmission onto VTA DA neurons at physiological temperatures in vitro. This observation is in accordance with similar forms of transient inhibition of excitatory synaptic inputs mediated by endocannabinoids in other brain regions (for review, see Alger, 2002; Diana and Marty, 2004). Importantly, this phenomenon occurs under stimulation conditions resembling the physiological range of PFC neuronal activity during the performance of PFC-dependent cognitive tasks (Jackson et al., 2001). It is worth mentioning that we cannot identify definitively the sources of excitatory afferents in the slice preparation; however, because the major excitatory input to the VTA comes from the prefrontal cortex (Kalivas, 1993; Overton and Clark, 1997), we can assume that most of the rostral inputs that are stimulated electrically in our preparation are cortical inputs. Accordingly, activation of CB1 receptors in vivo decreases VTA DA cell spiking and bursting probability evoked by PFC stimulation; however, because of systemic administration of the drugs, we cannot exclude the possibility that the effects are caused by activation of CB1 receptor in other brain regions. Nonetheless, when the in vivo and in vitro results are taken together, they indicate that the endocannabinoid system might operate locally as a device for the DA neurons to switch their firing pattern and activity in response to stimuli.

Modulation of glutamatergic afferents plays an important role in regulating VTA DA neuronal activity (Overton and Clark, 1997), especially in mediating the switch from pacemaker-like to burst-firing pattern (Gariano and Groves, 1988; Svensson and Tung, 1989; Johnson et al., 1992; Murase et al., 1993; Zhang et al., 1994). Importantly, burst firing of DA neurons leads to larger and transient extracellular DA concentrations as compared with single spiking (Gonon, 1988). Indeed, transient and phasic increases of DA levels in the target regions (subcortical and cortical) are associated with increased bursting probability as well as reward- 
ing and alerting stimuli (Rebec et al., 1997; Robinson et al., 2001; Wightman and Robinson, 2002). Furthermore, phasic released DA serves distinct physiological and behavioral functions depending on the target area: subcortical DA influences motivation, psychomotor activation, and reward craving, whereas cortical DA has an effect on working memory, stress, and reward anticipation (Jentsch et al., 2000; Wightman and Robinson, 2002). As a result, the endocannabinoid system, by shaping the VTA DA neuronal pattern of activity and ultimately fine-tuning tonic versus phasic DA transmission, might enable or disrupt, respectively, DA modulation of the information connecting limbic and motor systems. Indeed, the VTA DA neuronal firing pattern has long been implicated in processing information about the rewarding and motivationally relevant properties of external stimuli (White, 1996; Overton and Clark, 1997; Schultz, 1998). Thus, the finding that VTA DA cells respond to PFC stimulation with an increased spiking and bursting probability, as well as an augmented frequency within the bursts, when the endocannabinoid retrograde signal is disrupted, strongly suggests that this retrograde signal might attribute incentive salience to otherwise irrelevant stimuli and also be involved in altered stress responses (such as those observed in CB1 knock-out mice) (Marsicano et al., 2002; Haller et al., 2004). Indeed, phasic and transient DA release occurs in response to a new environment (Rebec et al., 1997) and/or stimulus (Robinson et al., 2001), consistent with the idea that phasic DA serves as an alerting signal, and contributes to associative phases of reward (Wightman and Robinson, 2002). On the other hand, activation of CB1 receptors after Cannabis use transiently induces cognitive deficits (e.g., impaired attention, altered perception, lack of motivation, and deficits in working memory) (D'Souza et al., 2004) resembling those associated with endogenous psychotic disorders such as schizophrenia. Therefore, we suggest that a functional endocannabinoid system might be the possible candidate for the modulation of those cortical afferents that provide a filter for nonsalient information and are disrupted by long-term Cannabis abuse (Solowij et al., 1991). Indeed, here we report that the retrograde signal occurring at $\mathrm{PFC} \rightarrow$ VTA synapses requires a functional endocannabinoid system. Synthesis and release of 2-AG from VTA DA cells and subsequent activation of presynaptic CB1 receptors are essential conditions for the development and occurrence of this suppression of excitation. In fact, both blockade and occlusion of CB1 receptors, with AM281 and WIN, respectively, prevented suppression of excitation, suggesting a common target with the endogenous retrograde signal. In addition, train-induced suppression of excitation is absent in $\mathrm{CB} 1^{-1-}$ mice, thus providing conclusive evidence for activation of $\mathrm{CB} 1$ receptors by endocannabinoids. Furthermore, we showed that this phenomenon was abolished when $s n-1-D A G$ lipase and PI-PLC activity were inhibited. Consequently, 2-AG is the most likely retrograde messenger required for the observed suppression of excitation. 2-AG, as well as anandamide, is a substrate of the putative endocannabinoid transporter (Beltramo et al., 1997; Bisogno et al., 2001). Blockade of endocannabinoid transporter could result either in augmented half-life of endocannabinoids (Beltramo et al., 1997) or in a reduced extracellular reverse transport when applied extracellularly and intracellularly, respectively (Ronesi et al., 2004). When applied extracellularly, endocannabinoid transporter blockers such as OMDM-2 and VDM-11 are ineffective (Marinelli and Mercuri, 2004; Ronesi et al., 2004), thus supporting the hypothesis that reverse transport is necessary for endocannabinoid release; however, caution is emphasized when interpreting these results, because a possible confounding factor might be that both
CB1 and vanilloid (VR1) receptors are found on glutamatergic terminals onto DA neurons (Marinelli and Mercuri, 2004). Consequently, increases in the half-life of endocannabinoids, such as anandamide or $\mathrm{N}$-arachidonyldopamine, which also activate VR1 receptors, are expected to exert opposite actions on glutamate release and might result in an overall lack of measurable effects. In fact, OMDM-2, when applied extracellularly in the absence of either CB1 or VR1 receptor antagonists, has been found to be ineffective on basal excitatory synaptic transmission on DA neurons (Marinelli and Mercuri, 2004). Accordingly, we found that VDM-11 was without significant effect on stimulusevoked activity of DA neurons. In fact, the actions of this drug could be the result of differential or region-specific effects.

Consistent with previous observations in the VTA (Melis et al., 2004), endocannabinoid-mediated suppression of excitation depends on rises in postsynaptic $\mathrm{Ca}^{2+}$. Mobilization of $\mathrm{Ca}^{2+}$ from the intracellular stores, rather than from the extracellular space through voltage-gated $\mathrm{Ca}^{2+}$ channels, is necessary for 2-AG retrograde inhibition. Last, the requirement for activation of mGluR1, but not NMDA or $\mathrm{D}_{2} \mathrm{DA}$ receptors, indicates a need for low-to-moderate glutamatergic activation but not a strong postsynaptic depolarization. Indeed, glutamate activates the majority of mGluRs at submicromolar concentrations, whereas it stimulates ionotropic receptors at higher concentrations (Harata et al., 1996; Schoepp et al., 1999). Importantly, the observation that CPCCOEt fully blocks train-induced suppression of excitation is in agreement with a mGluR1-mediated effect (Batchelor et al., 1997; Guatteo et al., 1999; Litschig et al., 1999). In addition, the lack of effect of MPEP indicates that mGluR5 is not involved, which is consistent with the expression of the mGluR1 subtype in DA cells (Testa et al., 1994; Kosinski et al., 1998). Interestingly, it has been reported that tetanic stimulation of excitatory fibers induces slow mGluR1-mediated excitatory and inhibitory responses (Shen and Johnson, 1997; Fiorillo and Williams, 1998) accompanied by rapid increases in intracellular $\mathrm{Ca}^{2+}$ attributable to mobilization from the intracellular stores (Fiorillo and Williams, 1998; Guatteo et al., 1999; Morikawa et al., 2000). Thus, it might be speculated that rises in intracellular $\mathrm{Ca}^{2+}$ leading to endocannabinoid synthesis and release might result from activation of intracellular pathways downstream of the activation of mGluR1. The conclusion that mGluR1 activation might trigger endocannabinoid release is in accordance with previous observations at both excitatory and inhibitory synapses in several brain regions (Maejima et al., 2001; Varma et al., 2001; Brown et al., 2003; Chevaleyre and Castillo, 2003; Galante and Diana, 2004). Indeed, group I mGluRs are positively coupled to PLC, which in turn increases intracellular levels of $\mathrm{IP}_{3}$ (and consequently $\mathrm{Ca}^{2+}$ levels mediated by intracellular stores) and DAG (which is itself a precursor of 2-AG). Hence, it appears conceivable that mGluR1 activation would preferentially lead to $2-A G$ production through one or both of these signaling pathways.

Probably because of the fact that 2-AG has been discovered only recently (Mechoulam et al., 1995; Sugiura et al., 1995) and the first isolated endocannabinoid anandamide still remains in the spotlight of the endocannabinoid field of research, very little is known about the physiological role of this monoacylglycerol (Stella et al., 1997; Ameri and Simmet, 2000; Witting et al., 2004); however, 2-AG is the most abundant endocannabinoid in tissues (Mechoulam et al., 1995; Sugiura et al., 1995), and its concentrations in the mesencephalon are 100 times higher than anandamide (Bisogno et al., 1999b). In addition, 2-AG acts as a potent and full agonist at CB1 receptors, whereas anandamide is only a partial agonist (Sugiura et al., 1995, 1999; Stella et al., 1997; Savi- 
nainen et al., 2001). Our conclusion that 2-AG is the retrograde messenger at these synapses supports its involvement in the modulation of excitatory neurotransmission via activation of presynaptic $\mathrm{CB} 1$ receptors reported in other brain regions, such as the hippocampus (Stella et al., 1997; Ameri and Simmet, 2000).

Because the physiological significance of 2-AG signaling at $\mathrm{PFC} \rightarrow \mathrm{VTA}$ synapses is reflected in the activity of VTA DA cells in response to PFC stimulation, 2-AG might ultimately fine-tune phasic versus tonic DA release in the terminal regions. These considerations highlight how finely the endocannabinoid system might regulate DA modulation of cortical information processing and help explain the correlation between unbalanced endocannabinoid signal and altered DA-dependent processes under conditions of stress, drug abuse, and other psychiatric disorders such as schizophrenia. Thus, further comprehension of the endocannabinoid retrograde signaling in VTA DA neurons might help us understand the pathophysiology of psychiatric disorders such as schizophrenia and addiction that are thought to be associated with abnormalities in both PFC and DA function.

\section{References}

Alger BE (2002) Retrograde signaling in the regulation of synaptic transmission: focus on endocannabinoids. Prog Neurobiol 68:247-286.

Ameri A, Simmet T (2000) Effects of 2-arachidonylglycerol, an endogenous cannabinoid, on neuronal activity in rat hippocampal slices. Naunyn Schmiedebergs Arch Pharmacol 361:265-272.

Batchelor AM, Knopfel T, Gasparini F, Garthwaite J (1997) Pharmacological characterization of synaptic transmission through mGluRs in rat cerebellar slices. Neuropharmacology 36:401-403.

Beltramo M, Stella N, Calignano A, Lin SY, Makriyannis A, Piomelli D (1997) Functional role of high-affinity anandamide transport, as revealed by selective inhibition. Science 277:1094-1097.

Bisogno T, Melck D, De Petrocellis L, Di Marzo V (1999a) Phosphatidic acid as the biosynthetic precursor of the endocannabinoid 2-arachidonoylglycerol in intact mouse neuroblastoma cells stimulated with ionomycin. J Neurochem 72:2113-2119.

Bisogno T, Berrendero F, Ambrosino G, Cebeira M, Ramos JA, FernandezRuiz JJ, Di Marzo V (1999b) Brain regional distribution of endocannabinoids: implications for their biosynthesis and biological function. Biochem Biophys Res Commun 256:377-380.

Bisogno T, Maccarrone M, De Petrocellis L, Jarrahian A, Finazzi-Agro A, Hillard C, Di Marzo V (2001) The uptake by cells of 2-arachidonoylglycerol, an endogenous agonist of cannabinoid receptors. Eur J Biochem 268:1982-1989.

Bisogno T, Howell F, Williams G, Minassi A, Cascio MG, Ligresti A, Matias I, Schiano-Moriello A, Paul P, Williams EJ, Gangadharan U, Hobbs C, Di Marzo V, Doherty P (2003) Cloning of the first sn1-DAG lipases points to the spatial and temporal regulation of endocannabinoid signaling in the brain. J Cell Biol 163:463-468.

Brown SP, Brenowitz SD, Regehr WG (2003) Brief presynaptic bursts evoke synapse-specific retrograde inhibition mediated by endogenous cannabinoids. Nat Neurosci 6:1048-1057.

Calignano A, La Rana G, Giuffrida A, Piomelli D (1998) Control of pain initiation by endogenous cannabinoids. Nature 394:277-281.

Chevaleyre V, Castillo PE (2003) Heterosynaptic LTD of hippocampal GABAergic synapses: a novel role of endocannabinoids in regulating excitability. Neuron 38:461-472.

Christie MJ, Bridge S, James LB, Beart PM (1985) Excitotoxin lesions suggest an aspartatergic projection from rat medial prefrontal cortex to ventral tegmental area. Brain Res 333:169-172.

Diana MA, Marty A (2004) Endocannabinoid-mediated short-term synaptic plasticity: depolarization-induced suppression of inhibition (DSI) and depolarization-induced suppression of excitation (DSE). Br J Pharmacol 142:9-19.

Di Marzo V, Fontana A, Cadas H, Schinelli S, Cimino G, Schwartz JC, Piomelli D (1994) Formation and inactivation of endogenous cannabinoid anandamide in central neurons. Nature 372:686-691.

Di Marzo V, Melck D, Bisogno T, De Petrocellis L (1998) Endocannabinoids: endogenous cannabinoid receptor ligands with neuromodulatory action. Trends Neurosci 21:521-528.
Di Marzo V, Breivogel CS, Tao Q, Bridgen DT, Razdan RK, Zimmer AM, Zimmer A, Martin BR (2000) Levels, metabolism, and pharmacological activity of anandamide in $\mathrm{CB}(1)$ cannabinoid receptor knockout mice: evidence for non- $\mathrm{CB}(1)$, non- $\mathrm{CB}(2)$ receptor-mediated actions of anandamide in mouse brain. J Neurochem 75:2434-2444.

D’Souza DC, Perry E, MacDougall L, Ammerman Y, Cooper T, Wu YT, Braley G, Gueorguieva R, Krystal JH (2004) The psychotomimetic effects of intravenous delta-9-tetrahydrocannabinol in healthy individuals: implications for psychosis. Neuropsychopharmacology 29:1558-1572.

Fiorillo CD, Williams JT (1998) Glutamate mediates an inhibitory postsynaptic potential in dopamine neurons. Nature 394:78-82.

Fortin DA, Trettel J, Levine ES (2004) Brief trains of action potentials enhance pyramidal neuron excitability via endocannabinoid-mediated suppression of inhibition. J Neurophysiol 92:2105-2112.

Fride E, Foox A, Rosenberg E, Faigenboim M, Cohen V, Barda L, Blau H, Mechoulam R (2003) Milk intake and survival in newborn cannabinoid $\mathrm{CB}(1)$ receptor knockout mice: evidence for a " $\mathrm{CB}(3)$ " receptor. Eur J Pharmacol 461:27-34.

Galante M, Diana MA (2004) Group I metabotropic glutamate receptors inhibit GABA release at interneuron-Purkinje cell synapses through endocannabinoid production. J Neurosci 24:4865-4874.

Gariano RF, Groves PM (1988) Burst firing induced in midbrain dopamine neurons by stimulation of the medial prefrontal and anterior cingulate cortices. Brain Res 462:194-198.

Gonon FG (1988) Nonlinear relationship between impulse flow and dopamine released by rat midbrain dopaminergic neurons as studied by in vivo electrochemistry. Neuroscience 24:19-28.

Grace AA (1991) Phasic versus tonic dopamine release and the modulation of dopamine system responsivity: a hypothesis for the etiology of schizophrenia. Neuroscience 41:1-24.

Grace AA, Bunney BS (1983) Intracellular and extracellular electrophysiology of nigral dopaminergic neurons-1. Identification and characterization. Neuroscience 10:301-315.

Grace AA, Bunney BS (1984) The control of firing pattern in nigral dopamine neurons: burst firing. J Neurosci 4:2877-2890.

Grace AA, Onn SP (1989) Morphology and electrophysiological properties of immunocytochemically identified rat dopamine neurons recorded in vitro. J Neurosci 9:3463-3481.

Guatteo E, Mercuri NB, Bernardi G, Knopfel T (1999) Group I metabotropic glutamate receptors mediate an inward current in rat substantia nigra dopamine neurons that is independent from calcium mobilization. J Neurophysiol 82:1974-1981.

Guyenet PG, Aghajanian GK (1978) Antidromic identification of dopaminergic and other output neurons of the rat substantia nigra. Brain Res 150:69-84.

Hajos N, Freund TF (2002a) Pharmacological separation of cannabinoid sensitive receptors on hippocampal excitatory and inhibitory fibers. Neuropharmacology 43:503-510.

Hajos N, Freund TF (2002b) Distinct cannabinoid sensitive receptors regulate hippocampal excitation and inhibition. Chem Phys Lipids 121:73-82.

Hajos N, Ledent C, Freund TF (2001) Novel cannabinoid-sensitive receptor mediates inhibition of glutamatergic synaptic transmission in the hippocampus. Neuroscience 106:1-4.

Haller J, Varga B, Ledent C, Barna I, Freund TF (2004) Context-dependent effects of CB1 cannabinoid gene disruption on anxiety-like and social behaviour in mice. Eur J Neurosci 19:1906-1912.

Hampson RE, Zhuang SY, Weiner JL, Deadwyler SA (2003) Functional significance of cannabinoid-mediated, depolarization-induced suppression of inhibition (DSI) in the hippocampus. J Neurophysiol 90:55-64.

Harata N, Katayama J, Takeshita Y, Murai Y, Akaike N (1996) Two components of metabotropic glutamate responses in acutely dissociated CA3 pyramidal neurons of the rat. Brain Res 711:223-233.

Jackson ME, Frost AS, Moghaddam B (2001) Stimulation of prefrontal cortex at physiologically relevant frequencies inhibits dopamine release in the nucleus accumbens. J Neurochem 78:920-923.

Jarai Z, Wagner JA, Varga K, Lake KD, Compton DR, Martin BR, Zimmer AM, Bonner TI, Buckley NE, Mezey E, Razdan RK, Zimmer A, Kunos G (1999) Cannabinoid-induced mesenteric vasodilation through an endothelial site distinct from $\mathrm{CB} 1$ or $\mathrm{CB} 2$ receptors. Proc Natl Acad Sci USA 96:14136-14141.

Jentsch JD, Roth RH, Taylor JR (2000) Role for dopamine in the behavioral 
functions of the prefrontal corticostriatal system: implications for mental disorders and psychotropic drug action. Prog Brain Res 126:433-453.

Johnson SW, North RA (1992) Two types of neurone in the rat ventral tegmental area and their synaptic inputs. J Physiol (Lond) 450:455-468.

Kalivas PW (1993) Neurotransmitter regulation of dopamine neurons in the ventral tegmental area. Brain Res Rev 18:75-113.

Kosinski CM, Standaert DG, Testa CM, Penney Jr JB, Young AB (1998) Expression of metabotropic glutamate receptor 1 isoforms in the substantia nigra pars compacta of the rat. Neuroscience 86:783-798.

Lichtman AH, Varvel SA, Martin BR (2002) Endocannabinoids in cognition and dependence. Prostaglandins Leukot Essent Fatty Acids 66:269-285.

Litschig S, Gasparini F, Rueegg D, Stoehr N, Flor PJ, Vranesic I, Prezeau L, Pin JP, Thomsen C, Kuhn R (1999) CPCCOEt, a noncompetitive metabotropic glutamate receptor 1 antagonist, inhibits receptor signaling without affecting glutamate binding. Mol Pharmacol 55:453-461.

Lutz B (2002) Molecular biology of cannabinoid receptors. Prostaglandins Leukot Essent Fatty Acids 66:123-142.

Maejima T, Hashimoto K, Yoshida T, Aiba A, Kano M (2001) Presynaptic inhibition caused by retrograde signal from metabotropic glutamate to cannabinoid receptors. Neuron 31:463-475.

Marinelli S, Mercuri NB (2004) Cannabinoid and vanilloid receptors are activated by $\mathrm{N}$-arachidonyl-dopamine in rat midbrain dopaminergic neurons. Paper presented at International Cannabinoid Research Society, 2004 Symposium on the Cannabinoids, Burlington, VT, June.

Marsicano G, Wotjak CT, Azad SC, Bisogno T, Rammes G, Cascio MG, Hermann H, Tang J, Hofmann C, Zieglgansberger W, Di Marzo V, Lutz B (2002) The endogenous cannabinoid system controls extinction of aversive memories. Nature 418:530-534.

Matsuda LA, Lolait SJ, Brownstein MJ, Young AC, Bonner TI (1990) Structure of a cannabinoid receptor and functional expression of the cloned cDNA. Nature 346:561-564.

Mechoulam R, Ben-Shabat S, Hanus L, Ligumsky M, Kaminski NE, Schatz AR, Gopher A, Almog S, Martin BR, Compton DR (1995) Identification of an endogenous 2-monoglyceride, present in canine gut, that binds to cannabinoid receptors. Biochem Pharmacol 50:83-90.

Melis M, Pistis M, Perra S, Muntoni AL, Pillolla G, Gessa GL (2004) Endocannabinoids mediate presynaptic inhibition of glutamatergic transmission in rat ventral tegmental area dopamine neurons through activation of CB1 receptors. J Neurosci 24:53-62.

Morikawa H, Imani F, Khodakhah K, Williams JT (2000) Inositol 1,4,5triphosphate-evoked responses in midbrain dopamine neurons. J Neurosci 20:RC103(1-5).

Morikawa H, Khodakhah K, Williams JT (2003) Two intracellular pathways mediate metabotropic glutamate receptor-induced $\mathrm{Ca}^{2+}$ mobilization in dopamine neurons. J Neurosci 23:149-157.

Murase S, Grenhoff J, Chouvet G, Gonon FG, Svensson TH (1993) Prefrontal cortex regulates burst firing and transmitter release in rat mesolimbic dopamine neurons studied in vivo. Neurosci Lett 157:53-56.

Ohno-Shosaku T, Shosaku J, Tsubokawa H, Kano M (2002) Cooperative endocannabinoid production by neuronal depolarization and group I metabotropic glutamate receptor activation. Eur J Neurosci 15:953-961.

Ortar G, Ligresti A, De Petrocellis L, Morera E, Di Marzo V (2003) Novel selective and metabolically stable inhibitors of anandamide cellular uptake. Biochem Pharmacol 65:1473-1481.

Overton PG, Clark D (1997) Burst firing in midbrain dopaminergic neurons. Brain Res Brain Res Rev 25:312-334.

Paxinos G, Watson C (1997) The rat brain in stereotaxic coordinates. San Diego: Academic.

Piomelli D, Beltramo M, Glasnapp S, Lin SY, Goutopoulos A, Xie XQ, Makriyannis A (1999) Structural determinants for recognition and translocation by the anandamide transporter. Proc Natl Acad Sci USA 96:5802-5807.

Rebec GV, Grabner CP, Johnson M, Pierce RC, Bardo MT (1997) Transient increases in catecholaminergic activity in medial prefrontal cortex and nucleus accumbens shell during novelty. Neuroscience 76:707-714.

Robbe D, Kopf M, Remaury A, Bockaert J, Manzoni OJ (2002) Endogenous cannabinoids mediate long-term synaptic depression in the nucleus accumbens. Proc Natl Acad Sci USA 99:8384-8388.

Robinson DL, Phillips PE, Budygin EA, Trafton BJ, Garris PA, Wightman RM (2001) Sub-second changes in accumbal dopamine during sexual behavior in male rats. NeuroReport 12:2549-2552.

Ronesi J, Gerdeman GL, Lovinger DM (2004) Disruption of endocannabinoid release and striatal long-term depression by postsynaptic blockade of endocannabinoid membrane transport. J Neurosci 24:1673-1679.

Savinainen JR, Jarvinen T, Laine K, Laitinen JT (2001) Despite substantial degradation, 2-arachidonoylglycerol is a potent full efficacy agonist mediating $\mathrm{CB}(1)$ receptor-dependent $\mathrm{G}$-protein activation in rat cerebellar membranes. Br J Pharmacol 134:664-672.

Schoepp DD, Jane DE, Monn JA (1999) Pharmacological agents acting at subtypes of metabotropic glutamate receptors. Neuropharmacology 38:1431-1476.

Schultz W (1998) Predictive reward signal of dopamine neurons. J Neurophysiol 80:1-27.

Schultz W (2002) Getting formal with dopamine and reward. Neuron 36:241-263.

Shen KZ, Johnson SW (1997) A slow excitatory postsynaptic current mediated by G-protein-coupled metabotropic glutamate receptors in rat ventral tegmental dopamine neurons. Eur J Neurosci 9:48-54.

Solowij N, Michie PT, Fox AM (1991) Effects of long-term cannabis use on selective attention: an event-related potential study. Pharmacol Biochem Behav 40:683-688.

Stella N, Schweitzer P, Piomelli D (1997) A second endogenous cannabinoid that modulates long-term potentiation. Nature 388:773-778.

Sugiura T, Kondo S, Sukagawa A, Nakane S, Shinoda A, Itoh K, Yamashita A, Waku K (1995) 2-Arachidonoylglycerol: a possible endogenous cannabinoid receptor ligand in brain. Biochem Biophys Res Commun 215:89-97.

Sugiura T, Kodaka T, Nakane S, Miyashita T, Kondo S, Suhara Y, Takayama H, Waku K, Seki C, Baba N, Ishima Y (1999) Evidence that the cannabinoid CB1 receptor is a 2-arachidonoylglycerol receptor. Structureactivity relationship of 2-arachidonoylglycerol, ether-linked analogues, and related compounds. J Biol Chem 274:2794-2801.

Svensson TH, Tung CS (1989) Local cooling of pre-frontal cortex induces pacemaker-like firing of dopamine neurons in rat ventral tegmental area in vivo. Acta Physiol Scand 136:135-136.

Testa CM, Standaert DG, Young AB, Penney Jr JB (1994) Metabotropic glutamate receptor mRNA expression in the basal ganglia of the rat. J Neurosci 14:3005-3008.

Tong ZY, Overton PG, Clark D (1996a) Stimulation of the prefrontal cortex in the rat induces patterns of activity in midbrain dopaminergic neurons which resemble natural burst events. Synapse 22:195-208.

Tong ZY, Overton PG, Clark D (1996b) Antagonism of NMDA receptors but not AMPA/kainate receptors blocks bursting in dopaminergic neurons induced by electrical stimulation of the prefrontal cortex. J Neural Transm 103:889-904.

Varma N, Carlson GC, Ledent C, Alger BE (2001) Metabotropic glutamate receptors drive the endocannabinoid system in hippocampus. J Neurosci 21:RC188(1-6).

Walker JM, Huang SM, Strangman NM, Tsou K, Sanudo-Pena MC (1999) Pain modulation by release of the endogenous cannabinoid anandamide. Proc Natl Acad Sci USA 96:12198-12203.

White FJ (1996) Synaptic regulation of mesocorticolimbic dopamine neurons. Annu Rev Neurosci 19:405-436.

Wightman RM, Robinson DL (2002) Transient changes in mesolimbic dopamine and their association with "reward". J Neurochem 82:721-735.

Wise RA (1996) Neurobiology of addiction. Curr Opin Neurobiol 6:243-251.

Witting A, Walter L, Wacker J, Moller T, Stella N (2004) P2X7 receptors control 2-arachidonoylglycerol production by microglial cells. Proc Natl Acad Sci USA 101:3214-3219.

Zhang J, Chiodo LA, Freeman AS (1994) Influence of excitatory amino acid receptor subtypes on the electrophysiological activity of dopaminergic and nondopaminergic neurons in rat substantia nigra. J Pharmacol Exp Ther 269:313-321. 